\title{
FORMULASI BUBUR INSTAN MENGGUNAKAN KOMPOSIT TEPUNG KACANG MERAH DAN PATI GANYONG SEBAGAI MAKANAN SAPIHAN
}

\author{
(Formulation of Instant Porridge Using Red Beans Flour and Canna Starch Composite \\ as a Weaning Food)
}

${\text { Yustiyani }{ }^{1 *} \text { dan Budi Setiawan }}^{1}$

'Departemen Gizi Masyarakat, Fakultas Ekologi Manusia (FEMA), Institut Pertanian Bogor, Bogor 16680

\begin{abstract}
The purpose of this study was to formulate instant baby porridge as a source of protein weaning food based on red beans flour and canna starch composite. The design of this study was a complete randomized design with one factor which was the ratio of red beans flour and canna starch in composite composition as instant porridge ingredient (2:1, 3:1, and 4:1). Based on organoleptic test, $F 2$ which used red bean flour and starch canna ratio by 3:1 was the best formula. The optimal time to brew the instant porridge was 62 seconds with amount of water used was $3 \mathrm{ml} / \mathrm{g}$. The instant porridge bulk density was $0.61 \mathrm{~g} / \mathrm{ml}$ and water absorption was $4.67 \mathrm{~g} / \mathrm{g}$. This instant porridge contained $363 \mathrm{kcal} / 100 \mathrm{~g}, 16.57 \%$ protein, $1.48 \%$ fat, $70.84 \%$ total carbohydrate, $197.70 \mathrm{mg}$ calcium, $8.17 \mathrm{mg}$ zinc, and $16.48 \mathrm{mg}$ iron. Protein digestibility of this porridge was $79.83 \%$. As per $27 \mathrm{~g}$ serving size of this instant porridge can fulfill $22.25 \%$ protein, $55.25 \%$ iron, $27.63 \%$ zinc so that it can be claimed as food source of protein and zinc, and high iron.
\end{abstract}

Keywords: canna starch, instant porridge, red bean flour, weaning food

\begin{abstract}
ABSTRAK
Tujuan penelitian ini adalah memformulasikan bubur instan sebagai MP-ASI sumber protein berbahan dasar tepung komposit yaitu tepung kacang merah dan pati ganyong. Penelitian ini menggunakan desain rancangan acak lengkap dengan satu faktor yaitu perbandingan penggunaan tepung kacang merah dan pati ganyong dalam tepung komposit sebagai bahan dasar pembuatan bubur instan (2:1, 3:1, dan 4:1). Berdasarkan uji organoleptik, formula bubur instan terbaik adalah F2 dengan perbandingan tepung kacang merah dan pati ganyong sebesar 3:1. Waktu optimal penyeduhan bubur instan terbaik adalah 62 detik dengan volume air penyeduh $3 \mathrm{ml} / \mathrm{g}$. Densitas kamba bubur adalah sebesar $0.61 \mathrm{~g} / \mathrm{ml}$ dan daya serap air $4.67 \mathrm{~g} / \mathrm{g}$. Kandungan gizi bubur instan meliputi $363 \mathrm{kkal}$ energi/100 g, 16.57\% protein, 1.48\% lemak, 70.84\% karbohidrat total, 197.70 mg kalsium, $8.17 \mathrm{mg}$ seng, serta $16.48 \mathrm{mg}$ besi. Daya cerna protein adalah sebesar $79.83 \%$. Takaran saji bubur instan adalah $27 \mathrm{~g}$ yang dapat menyumbang $22.25 \%$ protein, $55.25 \%$ zat besi, $27.63 \%$ seng berdasarkan Acuan Label Gizi (ALG) anak usia 7-24 bulan sehingga dapat diklaim sebagai pangan sumber protein dan seng serta tinggi zat besi.
\end{abstract}

Kata kunci: bubur instan, makanan sapihan, pati ganyong, tepung kacang merah

"Korespondensi: Departemen Gizi Masyarakat, Fakultas Ekologi Manusia (FEMA), Institut Pertanian Bogor, Bogor 16680. Email: yustifatihvia@gmail.com 


\section{PENDAHULUAN}

Memasuki usia enam bulan, pemberian Air Susu Ibu (ASI) saja tidak dapat mencukupi kebutuhan gizi bayi yang semakin meningkat. Perkembangan koordinasi motorik saluran cerna juga telah memungkinkan bayi untuk menerima makanan dari luar (Grueger 2013). Untuk itu, bayi perlu mendapatkan asupan makanan dari luar yang biasa disebut sebagai makanan pendamping Air Susu Ibu (MP-ASI). Proses pemberian MP-ASI kepada bayi dilakukan secara bertahap mulai dari makanan dengan konsistensi lunak hingga mencapai konsistensi makanan keluarga.

Ganyong adalah jenis umbi lokal yang potensial dikembangkan di Indonesia (Wardayanie et al. 2008). Umbi ini mudah dibudidayakan dan masih sedikit dikembangkan sebagai produk makanan bayi. Pati ganyong memiliki viskositas yang cukup rendah dan stabil (Hung \& Morita 2005) sehingga potensial dikembangkan sebagai makanan bayi. Akan tetapi, pati ganyong memiliki kadar protein rendah (Richana \& Sunarti 2004), sehingga perlu ditambah protein dari bahan lain untuk mendapatkan kandungan yang sesuai dengan kebutuhan bayi. Pembuatan komposit pati ganyong dengan tepung kacang merah dapat menjadi alternatif bahan dasar MP-ASI. Kacang merah (Phaseolus vulgaris L) merupakan salah satu jenis kacang-kacangan yang potensial dan mudah didapat di Indonesia. Tepung kacang merah memiliki kandungan protein tinggi yang tidak jauh berbeda dengan kacang kedelai dan kacang hijau, bebas protein gluten (Siddiq et al. 2010), serta dapat diminimalkan kandungan zat anti gizinya melalui proses perendaman (Krupa 2008) dan pemasakan (Shimelis \& Rakshit 2006) sehingga potensial dikembangkan sebagai makanan bayi.

Oleh karena itu, perlu dilakukan penelitian untuk mengetahui formulasi bubur instan yang tepat dengan memperhatikan aspek penerimaan dan kebutuhan gizi bayi. Pengembangan produk bubur instan menggunakan komposit tepung kacang merah dan pati ganyong merupakan terobosan baru untuk menghasilkan MP-ASI yang mendukung pertumbuhan dan perkembangan bayi di atas 6 bulan.

\section{METODE}

\section{Desain, Tempat, dan Waktu}

Desain penelitian yang digunakan dalam penelitian ini adalah rancangan acak lengkap. Perlakuan yang diberikan adalah perbedaan jenis komposit sebagai bahan dasar pembuatan bubur instan berupa perbandingan tepung kacang merah dan pati ganyong dengan 3 taraf yaitu 2:1, 3:1, dan 4:1. Penelitian ini dilaksanakan pada bulan Juli hingga Desember 2012 bertempat di Laboratorium Pengolahan Pangan, Laboratorium Analisis Zat Gizi, serta Laboratorium Organoleptik Departemen Gizi Masyarakat, Fakultas Ekologi Manusia, Institut Pertanian Bogor; dan Laboratorium Pilot Plant Pusat Antar Universitas (PAU), Institut Pertanian Bogor.

\section{Bahan dan Alat}

Bahan yang digunakan dalam penelitian ini terdiri atas bahan utama dan bahan pendukung. Bahan utama adalah kacang merah yang diperoleh dari Pasar Anyar Bogor dan umbi ganyong umur 8 bulan yang diperoleh dari petani di Babakan Lebak Dramaga. Bahan kimia yang digunakan adalah akuades, air bebas ion, asam sulfat $\left(\mathrm{H}_{2} \mathrm{SO}_{4}\right)$, asam borat, boraks, $\mathrm{NaOH}$, buffer Na-fosfat, enzim a-amilase, dinitrosalisilat, larutan maltose standar, $\mathrm{HCl}$, larutan Luff, pereaksi vanadat-molibdat, enzim pepsin, enzim pankreatin, enzim termamil, larutan multi enzim (tripsin, kimotripsin, peptidase), dan bahan-bahan lainnya.

Peralatan yang digunakan dalam penelitian terdiri atas peralatan untuk membuat pati ganyong, tepung kacang merah, bubur instan, alat analisis, serta alat untuk uji organoleptik meliputi ayakan (100 mesh), drum dryer, blender, sealer, timbangan kasar, timbangan analitik, pH meter, termometer, centrifuge, oven, tanur, penangas air, labu kjeldahl, labu lemak, soxhlet, kondensor, alat-alat gelas, dan kuesioner uji organoleptik.

\section{Tahapan Penelitian}

Penelitian ini dilakukan dalam beberapa tahapan. Tahapan pertama adalah pembuatan bahan baku formula bubur instan yaitu tepung kacang merah dengan metode drum dryer (Ekawati 1999) dan pati ganyong dengan modifikasi metode ekstraksi (Richana \& Sunarti 2004), serta analisis kandungan gizinya. Tahapan kedua adalah formulasi produk. Sebagai bahan dasar, tepung komposit kacang merah dan pati ganyong akan menyumbangkan $60 \%$ dari keseluruhan bahan penyusun bubur instan. Perlakuan diberikan dalam tiga taraf, yaitu perbandingan tepung kacang merah dengan pati ganyong adalah berturut-turut sebagai berikut 2:1 (40\%:20\%), 3:1 (45\%:15\%), serta 4:1 (48\%:12\%).

Tahapan ketiga penelitian adalah uji organoleptik dan uji daya terima bubur instan terpilih. Uji organoleptik dilakukan terhadap 29 orang panelis semi terlatih untuk mengetahui penilaian terhadap mutu hedonik dan hedonik formula. Parameter yang diuji meliputi warna, aroma, rasa, dan tekstur yang diuji dalam skala garis dengan rentang penilaian 1-9. Setelah didapatkan formula terpilih berdasarkan uji organoleptik, dilakukan uji daya terima formula terpilih terhadap panelis tidak terlatih yang 
terdiri atas 30 orang ibu yang memiliki bayi usia 7-12 bulan. Pemilihan ibu bayi sebagai panelis menggunakan asumsi bahwa pada usia 7-12 bulan, ibu merupakan penentu menu makan yang dominan pada bayi. Parameter yang diukur adalah kesukaan ibu bayi terhadap warna, aroma, rasa, dan tekstur. Formula terpilih dianalisis sifat fisik yang meliputi uji seduh, waktu rehidrasi, densitas kamba, dan daya serap air, serta analisis kimia yang meliputi analisis proksimat, kadar serat pangan, kalsium, seng, besi, fosfor, dan daya cerna protein.

\section{Pengolahan dan Analisis Data}

Rancangan percobaan yang digunakan pada penelitian ini adalah rancangan acak lengkap (RAL) dengan perlakuan 3 formulasi bubur instan MP-ASI dan dua kali ulangan. Hasil penilaian organoleptik diolah dengan Microsoft Excel 2007 dan dianalisis menggunakan analisis sidik ragam menggunakan software SPSS 16 for Windows. Jika terdapat beda nyata maka analisis dilanjutkan dengan uji lanjut Duncan.

\section{HASIL DAN PEMBAHASAN}

\section{Kandungan Gizi Tepung Kacang Merah}

Tepung kacang merah yang dihasilkan dalam penelitian ini memiliki rendemen $10.39 \%$, lebih kecil dibandingkan dengan rendeman tepung kacang merah pada penelitian Ekawati (1999) yaitu 28.7\%. Tepung kacang merah yang dihasilkan dalam penelitian ini memiliki ukuran partikel yang lolos ayakan 100 mesh, sementara pada penelitian Ekawati (1999) hanya lolos ayakan 60 mesh. Kandungan gizi tepung kacang merah meliputi kadar air 14.40\%, kadar abu 2.19\%, kadar protein 2.23\% (bb), kadar lemak 2.10\% (bb), serta kadar karbohidrat 79.09\% (bb). Kandungan ini berbeda dengan penelitian Ekawati (1999) yaitu secara berturut-turut 9.96\%, 2.48\%, 18.05\%, $2.42 \%$, dan $67.09 \%$. Perbedaan ini diduga karena kadar air tepung kacang dalam penelitian ini sangat tinggi sehingga memengaruhi kandungan zat gizi lain dalam tepung yang dihasilkan. Kadar protein tepung kacang merah dalam penelitian ini sangat berbeda dengan kandungan pada penelitian Ekawati (1999) diduga karena pengaruh pengolahan melalui drum dryer. Arrage et al. (1992) menyatakan bahwa pengolahan tepung menggunakan drum dryer menurunkan 20\% kadar isoleusin dan 16\% metionin, meskipun secara kualitas ketersediaan proteinnya bertambah.

\section{Kandungan Gizi Pati Ganyong}

Pati ganyong dalam penelitian ini memiliki rendemen sebesar $4.18 \%$, lebih kecil dibandingkan penelitian-penelitian sebelumnya yaitu dalam ren- tang 7.04-12.93\% (Richana \& Sunarti 2004). Kandungan gizi pati ganyong meliputi kadar air 6.50\%, kadar abu $0.63 \%$, kadar protein 0.42\% (bb), kadar lemak 2.99\% (bb), serta kadar karbohidrat $89.46 \%$ (bb). Nilai ini sedikit berbeda dengan hasil penelitian Richana dan Sunarti (2004), yaitu berturut-turut $8.34 \%, 0.20 \%, 0.08 \%, 0.75 \%$, dan $90.63 \%$, dimana kadar air lebih rendah sementara kadar abu, protein, dan lemak lebih tinggi. Perbedaan ini diduga karena adanya proses pemasakan dan pengeringan pati ganyong dengan drum dryer sebagaimana dilaporkan oleh Mohammed et al. (2009) bahwa proses pemasakan dan pengeringan drum dryer dapat mengubah kandungan gizi bahan.

\section{Pembuatan Bubur Instan}

Pembuatan bubur instan dilakukan dengan mencampur bahan-bahan yaitu bahan utama (tepung komposit kacang merah dan pati ganyong), bahan pendamping (susu skim), dan bahan bumbu (tepung gula, garam, perisa vanila) menggunakan metode dry mixing. Proses pencampuran dilakukan dengan mengocok bahan berdasarkan urutan proporsinya dalam formula dari yang terkecil hingga terbesar. Pencampuran dengan tujuan ini dimaksudkan untuk menghasilkan campuran bubur yang homogen.

\section{Karakteristik Organoleptik Bubur Instan}

Karakteristik organoleptik bubur instan diamati dengan menggunakan uji mutu hedonik, uji hedonik, serta uji kesukaan formula terpilih. Profil mutu hedonik ketiga formula diilustrasikan dalam Gambar 1.

Parameter yang diukur dalam uji mutu hedonik dan hedonik terdiri atas 4 parameter utama, yaitu warna, aroma, rasa, dan tekstur. Untuk uji mutu hedonik, beberapa parameter dijabarkan secara lebih spesifik, yaitu aroma bumbu dan aroma langu untuk parameter aroma; kemanisan dan rasa kacang merah untuk parameter rasa; serta kekentalan dan kelembutan untuk parameter tekstur. Skala yang digunakan dalam uji ini meliputi garis kontinum dengan nilai 1-9 yang menghubungkan dua titik ekstrim sesuai masing-masing parameter. Uji mutu hedonik menunjukkan adanya perbedaan nyata pada rataan skor penilaian panelis untuk parameter kemanisan dan kekentalan $(p<0.05)$.

Penilaian panelis terhadap parameter kemanisan memiliki rentang nilai 4.85-5.62 (agak tidak manis hingga agak manis). Hasil uji ANOVA menunjukkan adanya perbedaan rataan kemanisan bubur $(p<0.05)$. Rasa manis umumnya berasal dari komponen gula sederhana yang berinteraksi dengan indera pengecap (Fernstrom et al. 2012). Proporsi gula dalam ketiga formula merupakan faktor tetap, sehingga diduga perbedaan kemanisan terjadi ka- 


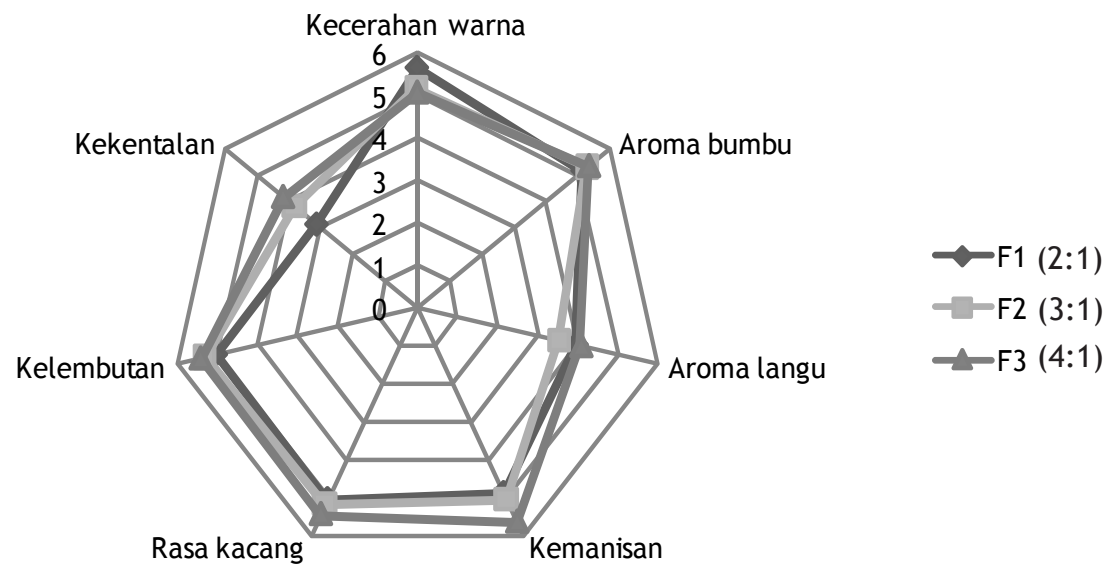

Gambar 1. Profil Mutu Hedonik

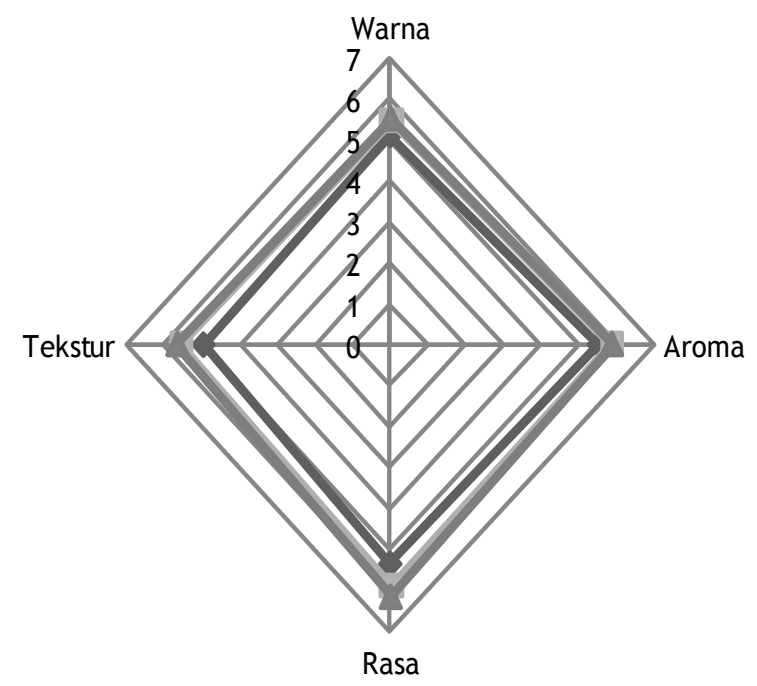

$\checkmark \mathrm{F} 1(2: 1)$

$-F 2(3: 1)$

$+\mathrm{F} 3(4: 1)$

Gambar 2. Profil Hedonik Formula

rena penurunan komposisi pati ganyong dalam formula komposit.

Rataan penilaian panelis terhadap parameter kekentalan bubur menunjukkan bahwa kekentalan bubur menurun sesuai dengan peningkatan perbandingan tepung kacang merah dan penurunan pati ganyong. Rataan penilaian panelis berkisar antara 3.12-4.18 (kental-agak kental). Hasil analisis sidik ragam menunjukkan adanya perbedaan yang nyata antara ketiga formula bubur instan $(p<0.05)$. Uji lanjut Duncan menunjukkan bahwa rataan skor formula F2 terletak dalam subset yang sama dengan formula F1 dan formula F3, tetapi formula F1 terletak dalam subset berbeda dengan F3.

Perbandingan tepung kacang merah yang semakin meningkat diduga menyebabkan penurunan kekentalan formula bubur karena tepung kacang merah mengandung lebih sedikit komponen karbohidrat dibandingkan pati ganyong. Shimelis et al. (2006) menyatakan bahwa tingginya kandungan komponen selain karbohidrat dan pati dalam suatu bahan khususnya kadar protein dan lemak akan memengaruhi swelling power dan sifat gelatinisasinya, sehingga kekentalan dalam bahan tersebut akan menurun.

Sementara itu, hasil uji hedonik menunjukkan adanya perbedaan nyata pada penilaian panelis untuk parameter rasa dan tekstur $(\mathrm{p}<0.05)$. Profil kesukaan panelis terhadap parameter warna, aroma, rasa, dan tekstur ketiga formula bubur instan disajikan dalam Gambar 2.

Kesukaan panelis terhadap parameter rasa bubur dalam uji hedonik berkisar pada penilaian biasa hingga suka dengan rataan nilai 5.33-6.16. Analisis sidik ragam menunjukkan adanya perbedaan kesukaan terhadap rasa ketiga formula bubur $(p<0.05)$. Hasil uji lanjut Duncan menyatakan bahwa rataan skor formula F2 dan F3 tidak berbeda nyata, sedangkan keduanya berbeda nyata dengan skor formula F1. Berdasarkan uji hedonik diketahui bahwa seluruh formula dapat diterima oleh panelis. Akan tetapi, formula F2 dan F3 cenderung lebih disukai. 
Uji hedonik terhadap parameter tekstur menunjukkan penilaian panelis berkisar dalam rentang agak tidak suka hingga agak suka. Kesukaan panelis meningkat dengan semakin meningkatnya perbadingan tepung kacang merah dan menurunnya pati ganyong. Hal ini diperkuat dengan analisis sidik ragam yang menunjukkan adanya perbedaan nyata antar formula $(p<0.05)$. Uji lanjut Duncan menyatakan formula F1 berbeda nyata dengan formula F2 dan F3.

Pemilihan formula terbaik untuk kepentingan analisis lebih lanjut didasarkan pada dua pertimbangan yaitu penerimaan panelis dan penggunaan pati ganyong sebagai umbi lokal yang diutamakan dalam komposisi bahan dasar. Berdasarkan penerimaan panelis, ketiga formula bubur instan dapat diterima karena memiliki rataan penerimaan lebih dari 5 (netral). Akan tetapi, formula F2 dan F3 memiliki penerimaan yang lebih tinggi dibandingkan F1. Pertimbangan kedua adalah pemilihan formula terbaik yang menggunakan lebih banyak perbandingan pati ganyong. Karena formula F2 menggunakan lebih banyak pati ganyong dibandingkan dengan formula F3, maka formula F2 dipilih sebagai formula terbaik yang akan dianalisis lebih lanjut.

Formula F2 selanjutnya diuji kesukaan terhadap ibu bayi. Sebanyak 30 orang ibu dengan bayi usia 7-12 bulan menilai kesukaan terhadap aspek warna, aroma, rasa, dan tekstur dari formula terpilih. Ibu menilai dalam lima skala yaitu 1-5 yang bermakna sangat tidak suka hingga sangat suka. Berdasarkan hasil uji kesukaan, diketahui bahwa rataan penilaian ibu terhadap parameter warna (4.37), aroma (4.23), rasa (4.60), dan tekstur (4.07) berada dalam rentang suka hingga sangat suka. Demikian pula kesukaan ibu secara keseluruhan (4.34) menunjukkan bahwa formula terpilih dapat diterima oleh ibu sebagai calon konsumen produk.

\section{Sifat Fisik Bubur Instan Terbaik}

Bubur instan terbaik memiliki volume air seduh sebesar $3 \mathrm{ml} / \mathrm{g}$ atau 3 bagian air dan 1 bagian bubur instan, dengan waktu optimal seduh selama 62 detik. Densitas kamba bubur instan terbaik adalah $0.61 \mathrm{~g} / \mathrm{ml}$, lebih tinggi dari densitas kamba produk MP-ASI komersial yaitu $0.40-0.49 \mathrm{~g} / \mathrm{ml}$ (Kusumaningrum \& Rahayu 2007). Produk pangan bayi diharapkan memiliki densitas kamba yang tinggi yang berarti kepadatan gizinya juga tinggi karena saluran cerna bayi terbatas sehingga tidak dapat menampung terlalu banyak makanan. Daya serap air formula terpilih $(4.67 \mathrm{~g} / \mathrm{g})$ berada dalam rentang nilai produk MP-ASI komersial yaitu $3.60-6.20 \mathrm{~g} / \mathrm{g}$. Daya serap air berkaitan dengan sifat kelarutan tepung saat ditambah air. Nilai daya serap air yang semakin besar menunjukkan bahwa bubur semakin mudah larut dalam air sehingga memudahkan pada saat proses penyeduhan (Kusumaningrum \& Rahayu 2007).

\section{Kandungan Gizi Bubur Instan Terbaik}

Kadar air. Kadar air produk berhubungan erat dengan daya simpannya. Semakin rendah kadar air suatu produk maka daya simpannya diperkirakan akan lebih lama. Kadar air formula bubur bayi terpilih adalah $7.92 \%$. Nilai ini lebih tinggi dari nilai yang disyaratkan dalam SNI No. 01-7111.1-2005 tentang Makanan Pendamping Air Susu Ibu (MP-ASI)-Bubuk Instan yaitu sebesar $4 \%$. Metode pengeringan pati ganyong dan tepung kacang merah diduga memberikan kontribusi terhadap tingginya kadar air. Hsu et al. (2003) menyatakan bahwa metode pengeringan drum cocok digunakan untuk mengeringkan bahan berbentuk pasta, tetapi menghasilkan tepung dengan kadar air lebih tinggi dibandingkan metode pengeringan lain.

Kadar abu. Kadar abu mengindikasikan kandungan mineral dalam bahan pangan. Kadar abu dalam formula bubur bayi instan terbaik adalah sebesar $3.19 \%$. Nilai ini telah sesuai dengan batas maksimal SNI yaitu sebesar 3.5\%.

Kadar protein. Kadar protein bubur bayi instan terbaik adalah sebesar $16.57 \%$. Nilai ini termasuk dalam rentang yang disyaratkan oleh SNI yaitu sebesar $8-22 \%$, sehingga tergolong aman dikonsumsi oleh bayi. Protein berkualitas tinggi sangat penting bagi bayi karena diperlukan dalam pembentukan jaringan baru, enzim, hormon, antibodi, dan fungsifungsi lain dalam tubuh (Grueger 2013).

Kadar lemak. Kadar lemak dalam formula terbaik tergolong rendah yaitu hanya sebesar $1.48 \%$. SNI mengenai MP-ASI bubuk instan mensyaratkan kandungan lemak tidak kurang dari 6\% dan tidak lebih dari 15\%. Rendahnya kadar lemak dalam formula ini diduga karena rendahnya kandungan lemak bahan utama yang tidak didukung dengan sumber lemak dari bahan lain.

Kadar karbohidrat. Kadar karbohidrat ditentukan menggunakan metode by difference dengan mengurangkan 100 dengan jumlah air, abu, protein, serta lemak. Perhitungan tersebut menghasilkan kadar karbohidrat total dalam formula terbaik sebesar $70.84 \%$. SNI mengenai produk MP-ASI bubuk instan tidak mensyaratkan jumlah karbohidrat total yang harus dipenuhi dalam produk bubur instan. Grueger (2013) menyatakan bahwa karbohidrat diperlukan oleh bayi sebagai sumber utama energi yang memungkinkan penggunaan protein secara optimal untuk pertumbuhan dan perkembangan.

Kadar serat pangan total. Kadar serat pangan total menunjukkan jumlah karbohidrat yang tidak dapat dicerna dalam saluran cerna manusia. 
Kadar serat perlu menjadi perhatian dalam produk pangan untuk bayi karena sistem pencernaan bayi belum sempurna sehingga dikhawatirkan dapat menimbulkan diare apabila ditemukan dalam jumlah besar. Kadar serat pangan total formula bubur instan bayi adalah sebesar $21.79 \%$. Nilai ini melebihi batas yang telah ditetapkan SNI yaitu sebesar 5\%. Kadar serat pangan yang tinggi selain berasal dari bahan asal diduga juga berasal dari komponen pati resisten yang terbentuk selama proses produksi yaitu pemasakan dan drum drying. Hal ini sejalan dengan temuan Mohammed et al. (2009) yang menyatakan bahwa proses pemasakan dilanjutkan dengan pengeringan drum dryer dapat meningkatkan kadar serat dalam tepung komposit.

Kadar kalsium. Kalsium merupakan salah satu mineral makro yang penting bagi pertumbuhan bayi. Kadar kalsium formula bubur bayi instan adalah sebesar 197.7 mg/100 g formula. Kadar ini sedikit lebih kecil dari jumlah yang disyaratkan SNI yaitu sebesar $200 \mathrm{mg} / 100 \mathrm{~g}$ produk.

Kadar seng. Mineral seng sangat diperlukan dalam pembentukan daya tahan bayi. Kadar seng dalam formula bubur bayi instan terbaik adalah sebesar $8.17 \mathrm{mg} / 100 \mathrm{~g}$. Jumlah ini telah memenuhi syarat minimal SNI yaitu sebesar $2.5 \mathrm{mg} / 100 \mathrm{~g}$.

Kadar besi. Memasuki usia empat hingga enam bulan, cadangan zat besi dalam tubuh bayi semakin berkurang, sehingga perlu asupan zat besi dari makanan luar (Grueger 2013). Kadar besi dalam formula bubur bayi instan terpilih adalah sebesar $16.48 \mathrm{mg} / 100 \mathrm{~g}$. Jumlah ini telah memenuhi batas minimal SNI untuk kandungan zat besi yaitu 5 $\mathrm{mg} / 100 \mathrm{~g}$ bahan. Penggunaan kacang merah diduga memberikan sumbangan zat besi terhadap bubur sebagaimana dinyatakan oleh El Obeid et al. (2009) bahwa penambahan tepung Phaseolus vulgaris dalam formulasi mi secara signifikan meningkatkan kadar dan bioavailabilitas zat besi.

Daya cerna protein. Daya cerna protein mengindikasikan kemampuan enzim-enzim dalam mencerna protein yang terdapat dalam formula bubur bayi instan. Komposisi protein yang sebagian berasal dari kacang merah dikhawatirkan menurunkan daya cerna protein karena adanya kandungan zat anti gizi dalam kacang-kacangan. Akan tetapi, selama proses persiapan telah dilakukan perlakuan-perlakuan untuk meminimalisasi aktivitas zat-zat anti gizi.

Daya cerna protein dalam formula ini adalah sebesar 79.83\%. Nilai ini lebih besar dibandingkan standar yang telah ditetapkan dalam SNI yaitu $70 \%$. Tingginya daya cerna protein diduga karena aktivitas zat anti gizi terhambat selama proses pembuatan bahan dengan perlakuan perendaman, pemasakan, serta pemanasan (Shimelis \& Rakshit 2006). Hal ini juga sejalan dengan temuan Mohammed et al. (2009) bahwa proses pemasakan disertai dengan pengeringan drum dryer dapat meningkatkan daya cerna protein in vitro pada tepung komposit.

\section{Kontribusi Zat Gizi Bubur Instan terhadap Acuan Label Gizi (ALG)}

Penentuan ukuran takaran saji penting dilakukan untuk kepentingan saran penyajian dan pelabelan pangan. Jumlah dan kontribusi zat gizi bubur instan terbaik per takaran saji terhadap ALG anak usia 7-23 bulan disajikan dalam Tabel 1. Takaran saji bubur instan terbaik ditentukan berdasarkan perhitungan kontribusi energi bubur instan terhadap kecukupan energi bayi usia 7-12 tahun. Bayi pada usia tersebut memerlukan tambahan energi sebesar 30-45\% yang dibagi dalam 2-3 kali waktu makan. Satu takaran saji bubur instan ditentukan sebesar 27 g yang dapat menyumbangkan 15\% kecukupan energi bayi usia 7-11 bulan menurut AKG 2004. Berdasarkan analisis kontribusi zat gizinya, bubur instan terbaik memberi kontribusi protein sebesar 22.25\% ALG anak usia 7-23 bulan sehingga dapat diklaim sebagai pangan sumber protein. Menurut BPOM (2011), pangan yang dapat memenuhi 20-35\% protein ALG untuk kategori usia tertentu dikategorikan sebagai pangan sumber protein. Sementara itu, BPOM (2011) menyatakan syarat klaim untuk pangan dengan kandungan mineral tertentu adalah lebih dari $15 \%$ sebagai sumber mineral dan lebih dari $30 \%$ sebagai pangan tinggi mineral. Dengan demikian,

Tabel 1. Kandungan Zat Gizi Bubur Instan dan Kontribusinya terhadap Acuan Label Gizi 7-23 Bulan per Takaran Saji

\begin{tabular}{lcccc}
\hline \multicolumn{1}{c}{ Zat Gizi } & Kandungan Zat Gizi/100 g & Jumlah Zat Gizi/Takaran Saji & ALG 2007 & \% ALG \\
\hline Energi (kkal) & 363.00 & 98.00 & 800 & 12.25 \\
Karbohidrat (g) & 70.84 & 19.03 & 120 & 15.86 \\
Lemak (g) & 1.48 & 0.40 & 27 & 1.48 \\
Protein (g) & 16.57 & 4.45 & 20 & 22.25 \\
Besi (mg) & 16.48 & 4.42 & 8 & 55.25 \\
Seng (mg) & 8.17 & 2.21 & 8 & 27.63 \\
Kalsium (mg) & 197.70 & 53.10 & 480 & 11.06 \\
\hline
\end{tabular}


formula bubur terpilih dapat diklaim sebagai pangan sumber seng $(27.63 \%)$ dan pangan tinggi zat besi (55.25\%).

\section{KESIMPULAN}

Bubur bayi instan sumber protein dapat dibuat dengan bahan dasar komposit tepung kacang merah dan pati ganyong menggunakan metode pencampuran kering (dry mixing). Bahan-bahan yang digunakan dalam proses dry mixing merupakan bahan yang telah diinstanisasi sebelumnya sehingga dapat langsung dikonsumsi hanya dengan menyeduh dengan air panas. Formula terbaik berdasarkan penerimaan terbaik melalui uji organoleptik, kesesuaian sifat fisik dan kimia adalah formula F2 (pati ganyong 15\%: tepung kacang merah 45\%).

Berdasarkan kontribusinya terhadap ALG anak 7-23 bulan, formula bubur instan komposit tepung kacang merah dan pati ganyong dapat diklaim sebagai pangan sumber protein dan seng serta tinggi zat besi. Perbaikan selama proses produksi untuk mengurangi kadar air dan menurunkan total serat pangan perlu dilakukan untuk memenuhi syarat mutu produk sesuai SNI. Penambahan minyak atau sumber lemak lain perlu dilakukan untuk menutupi kekurangan lemak dalam formula. Penggunaan tepung komposit kacang merah dan pati ganyong dapat dikembangkan sebagai formulasi makanan untuk kelompok umur dengan kebutuhan serat lebih tinggi.

\section{UCAPAN TERIMA KASIH}

Terima kasih kepada PT. INDOFOOD SUKSES MAKMUR yang telah mendanai penelitian ini dalam kerangka program INDOFOOD RISET NUGRAHA 2012-2013.

\section{DAFTAR PUSTAKA}

Arrage JM, Barbeau WE, \& Johnson JM. 1992. Protein quality of whole wheat as affected by drum - drying and single - screw extrusion. J. Agric. Food. Chem, (40), 1943-1947.

[BPOM] Badan Pengawas Obat dan Makanan. 2011. Keputusan Kepala Badan Pengawas Obat dan Makanan tentang Pengawasan Klaim dalam Label dan Iklan Produk Pangan Olahan. BPOM, Jakarta.

[BSN] Badan Standarisasi Nasional. 2005. SNI: 017111.1-2005. Makanan Pendamping Air Susu Ibu (MP-ASI) - Bagian 2: Bubuk Instan. Dewan Standar Nasional Indonesia, Jakarta.

Ekawati D. 1999. Pembuatan cookies dari tepung kacang merah (Phaseolus vulgaris L) sebagai makanan pendamping ASI (MP-ASI) [skripsi]. Fakultas Pertanian, Institut Pertanian Bogor, Bogor.

El Obeid T, Fakhrawi D, \& Berghofer E. 2009. Iron bioavailability and organoleptic properties of sorghum and white beans noodles. International Journal of Arts and Sciences, 1(6), 262-271.

Fernstrom JD, Munger SD, Sclafani A, de Araujo AE, Roberts A, \& Molinary S. 2012. Mechanism of sweetness. Journal of Nutirition, 1S-8S.

Grueger B. 2013. Weaning from the breast. Paediatr Child Health, 18(4), 210.

Hsu CL, Chen W, Weng YM, \& Tseng CY. 2003. Chemical composition, physical properties, and antioxidant activity of yam flour as affected by different drying method. Food Chemistry, (83), 85-92.

Hung PV \& Morita N. 2005. Physicochemical properties and enzimatic digestibility of starch from edible canna (Canna edulis) grown in Vietnam. Carbohydrate Polymers, (61), 314-321.

Krupa U. 2008. Main nutritional and antinutritional composition of bean seeds: A review. Polish Journal of Food and Nutrition Science, 58(2), 149-155.

Kusumaningrum A \& Rahayu WP. 2007. Penambahan kacang-kacangan dalam formulasi makanan pendamping air susu ibu (MP-ASI) berbahan dasar pati aren (Arengapinnata (Wurmb) Mar). Jurnal Teknologi dan Industri Pangan, XVIII(2), 73-80.

Mohammed MA, Makki HMH, \& Mustafa Al. 2009. Effect of cooking and drum drying on the nutritive value of sorghum-pigeon pea composite flour. Pakistan Journal of Nutrition, 8(7), 988-992.

Richana N \& Sunarti TC. 2004. Karakterisasi sifat fisikokimia tepung umbi dan tepung pati dari umbi ganyong, suweg, ubikelapa, dan gembili. J.Pascapanen, 1(1), 29-37.

Shimelis EA, Meaza M, \& Rakshit S. 2006. Physicochemical properties, pasting behaviour, and functional characteristics of flour and starches from improves beans (Phaseolus vulgaris L.) varieties grown in East Africa. Agricultural Enginering International, (8), 5-15.

Shimelis EA \& Rakshit SK. 2006. Effect of processing on antinutrient and in vitro protein digestibility of kidney bean (Phaseolus vulgaris L.) varieties grown in East Africa. Food Chemistry, (103), 161-172.

Siddiq M, Ravi R, Harte JB, \& Dolan KD. 2010. Physical and functional characteristics of selected dry bean (Phaseolus vulgris L.) flours). Food Science and Technology, (42), 232-237. 
Wardayanie NIA, Susanti I, Aviana T, \& Herman AS. 2008. Potensi umbi-umbian dan serealia dalam menunjang diversifikasi pangan berbasis sumber daya lokal. Jurnal Riset Industri, 2(1), $35-43$. 